\section{Poengtert anestesilærebok for raske oppslag og eksamenslesing}

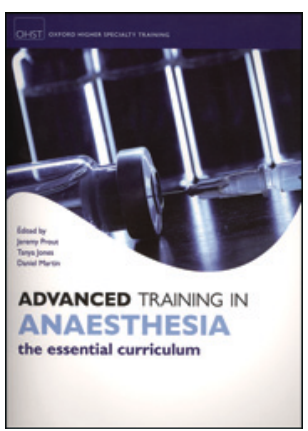

Jeremy Prout, Tanya Jones, Daniel Martin, red. Advanced training in anaesthesia

The essential curriculum. 558 s, tab, ill.

Oxford: Oxford University Press, 2014

Pris GBP 75

ISBN 978-0-19-960995-6

Dette er en bok i serien «Oxford Higher speciality training» og utgir seg for å inneholde alt en kandidat trenger for å ta sin endelige spesialisteksamen i Storbritannia. Den er lagt oppe etter pensum og spesifiserte krav fra The Royal College of Anaesthetists, og forutsetter at man har avlagt grunneksamen og lest første bok i samme serie, Training in anaesthesia (Spoors C, Kiff K, red.).

Advanced training in anaesthesia har to deler. den første inneholder 10 kapitler innenfor anvendt basalvitenskap, og den andre 17 kapitler innenfor klinisk anestesi. Over 70 forfattere har bidratt, nesten alle er klinikere basert i London. Det er lite innslag av profilerte forskere på internasjonalt nivå. Et spennende grep er at mange unge spesialistkandidater er med i forfattergruppen, sammen med erfarne seniorkolleger.

Hvert kapittel er tydelig delt opp i underkapitler for hvert tema, som behandles kortfattet og poengtert, med utstrakt bruk av korte tabeller og punktoppstillinger. Det er enkelte strekfigurer og en håndfull svart-hvitt illustrasjoner. Det faglige innholdet, bedømt ut fra stikkprøver, synes greit, men knapt, mange steder nesten i telegramstil. Forfatterne tar i liten grad opp diskusjoner om kontroversielle og nye temaer, men nøyer seg med å henvise til at dette er diskutert. Eksempelvis savnes en omtale av nye perorale antikoagulantia og hvordan de skal håndteres perioperativt.

Et savn for dem som vil bruke boken til ajourføring og oppdatering, er den svært begrensede bruken av referanser. De fleste underkapitlene har kun med 2-3 forslag til videre lesing, ofte britiske guidelines, andre lærebøker eller en litt tilfeldig valgt artikkel.

Et ytterligere savn for norske anestesiologer vil være den begrensede behandlingen av intensivmedisin, akuttmedisin, regionalanestesi, postoperativ medisin, smerteklinikk og prehospital medisin, kun korte, små kapitler. En annen begrensning er at basal anestesiologi, herunder farmakologi, behandles i den andre grunnboken, slik at spesialistkandidater ikke får én fullgod lærebok mellom to permer, men bør ha begge. Til tross for disse begrensingene fremstår det som er igjen som oversiktlig og lettlest, med godt poengterte overskrifter og avsnitt, og et fyldig stikkordregister til slutt. Det finnes en lang liste med forklaring av de mange forkortelsene, som ikke alltid er intuitive for en ikke-engelsk leser.

Boken kan anbefales for leger under spesialisering, men da sammen med en mer basal grunnbok og gjerne et oppslagsverk med mer utfyllende tekst og diskusjon om enkelte temaer. Den egner seg godt for dem som skal ta en internasjonal eksamen, fordi den oppsummerer og konkluderer greit innenfor mange temaer. For trenede anestesiologer kan boken være nyttig for et oppslag eller en rask, kortfattet oppsummering av et tema, men erstatter ikke mer omfattende oppslagsverk eller aktuelle oversiktsartikler.

\section{Johan Ræder}

Overlege, Avdeling for anestesiologi

Oslo universitetssykehus, Ullevål

\section{Helseøkonomisk evaluering som del av klinisk forskning}

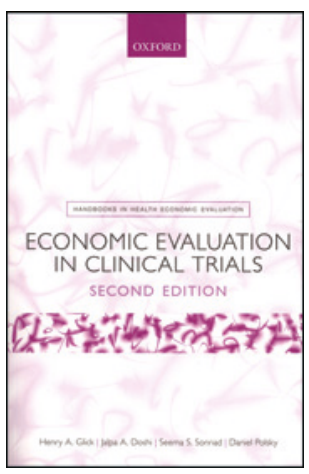

\author{
Henry A. Glick, Jalpa A. Doshi, \\ Seema S. Sonnad et al.
}

Economic evaluation in clinical trials

2 utg. 252 s, tab, ill. Oxford: Oxford University

Press, 2014. Pris GBP 35

ISBN 978-0-19-968502-8

Denne utgivelsens målgruppe er alle som planlegger å foreta en helseøkonomisk evaluering som del av en randomisert kontrollert studie. Boken er bygd opp rundt elleve kapitler og har i tillegg egne nettressurser. Stikkordregisteret gjør det lett å slå opp på enkelttemaer.

Economic evaluation in clinical trials er per dags dato den eneste læreboken om helseøkonomiske evalueringer som del av klinisk forskning. Denne andreutgaven er noe oppdatert og inneholder flere nye referanser, men det er ikke veldig store endringer fra førsteutgaven fra 2007. Boken er ikke primært en introduksjon til helseøkonomisk evaluering og heller ikke en innføring i randomiserte, kontrollerte studier (RCT). Derfor kan andre lærebøker med fordel konsulteres i tillegg, f.eks. Methods for the economic evaluation of health care programmes og Designing clinical research, med henholdsvis Michael Drummond og Stephen Hulley som førsteforfattere.

Kapitlene 1-6 gir en introduksjon til designmessige utfordringer ved å inkludere en økonomisk evaluering i en klinisk studie, råd angående hvordan man kan samle inn kostnader, finne priser, beregne kvalitetsjusterte leveår (QALY) og analysere kostnadsdata. Disse kapitlene fungerer godt og gir en fin innføring i mange relevante problemstillinger. Forfatterne skriver relativt mye om kostnader og analyser av kostnadsdata (tre kapitler), men tilvarende mindre om livskvalitet og analyser av livskvalitetsjusterte leveår (ett kapittel), noe som virker litt ubalansert. Eksempelvis nevnes problemer med manglende data kun i forbindelse med analyse av kostnader, til tross for at manglende data på livskvalitet er svært vanlig i randomiserte studier.

I kapitlene 7-9 beskrives indikatorer på kostnadseffektivitet («incremental cost effectiveness ratio» og «net monetary nenefit») og usikkerhet rundt disse. Mye plass vies til å diskutere situasjoner der konfidensintervall rundt den inkrementelle kostnad-effekt-brøken kan være vanskelig å tolke. Anbefalingen på slutten av kapittel $9 \mathrm{er}$ i tråd med det som ellers regnes som god praksis, nemlig å vise usikkerhet på kostnad-effekt-planet, men veien frem til denne anbefalingen er noe lang. Nyere metoder som analyse av verdien av videre forskning («value of information analysis») nevnes som alternative analyser av usikkerhet.

Kapittel 10 og 11 omhandler overførbarhet av økonomiske evaluering og relevansen av RCT-baserte økonomiske evalueringer.

Boken bør leses av dem som planlegger å gjennomføre en helseøkonomisk evaluering som del av en randomisert kontrollert studie, men andre lærebøker og publikasjoner bør konsulteres i tillegg.

\section{Gunhild Hagen}

Seniorrådgiver helseøkonomisk evaluering, Seksjon for legemidler og helseøkonomi

Nasjonalt kunnskapssenter for helsetjenesten 